\title{
Intake, digestibility, and rumen and metabolic characteristics of cattle fed low-quality tropical forage and supplemented with nitrogen and different levels of starch
}

\author{
Marcia de Oliveira Franco ${ }^{1, *}$, Edenio Detmann', Sebastião de Campos Valadares Filho', Erick Darlisson Batista', \\ Luana Marta de Almeida Rufino ${ }^{1}$, Marcília Medrado Barbosa', and Alexandre Ribeiro Lopes ${ }^{1}$
}

\begin{abstract}
* Corresponding Author: Marcia de Oliveira Franco Tel: +55-31-3899-2252, Fax: +55-31-3899-2275,

E-mail: marciazoo1@yahoo.com.br
\end{abstract}

' Department of Animal Science, Universidade Federal de Viçosa, Viçosa, MG 36570-000, Brazil

Submitted Aug 15, 2016; Revised Sept 24, 2016; Accepted Oct 24, 2016
Objective: Effects of nitrogen supplementation associated with different levels of starch on voluntary intake, digestibility, and rumen and metabolic characteristics of cattle fed low-quality tropical forage (Brachiaria decumbens hay, $7.4 \%$ crude protein, $\mathrm{CP}$ ) were evaluated using ruminal and abomasal cannulated steers.

Methods: Five European $\times$ Zebu young bulls ( $186 \mathrm{~kg}$ body weight, BW) were distributed according to a $5 \times 5$ Latin square. The following treatments were evaluated: control, supplementation with $300 \mathrm{~g} \mathrm{CP} / \mathrm{d}(0: 1)$, supplementation with $300 \mathrm{~g}$ starch/d and $300 \mathrm{~g} \mathrm{CP} / \mathrm{d}$ (1:1), supplementation with $600 \mathrm{~g}$ starch/d and $300 \mathrm{~g} \mathrm{CP} / \mathrm{d}$ (2:1), and supplementation with $900 \mathrm{~g}$ starch/d and $300 \mathrm{~g} \mathrm{CP} / \mathrm{d}$ (3:1). A mixture of nitrogenous compounds provided $1 / 3$ from true protein (casein) and 2/3 from non-protein nitrogen (mixture of urea and ammonium sulphate, 9:1) was used as the nitrogen supplement. In order to supply energy a unique source of corn starch was used.

Results: Supplements increased $(\mathrm{p}<0.05)$ dry matter intake, but did not affect $(\mathrm{p}>0.05)$ forage intake. There was a cubic effect $(\mathrm{p}<0.05)$ of starch on voluntary intake. This was attributed to the highest forage intake (g/kg BW) when using the 2:1 starch:CP ratio. Supplements increased $(p<0.05)$ organic matter $(O M)$ digestibility, but did not affect $(p>0.05)$ neutral detergent fibre corrected for ash and protein (NDFap) digestibility. There was a positive linear effect $(\mathrm{p}<0.05)$ of the amount of starch supplemented on OM digestibility. Total NDFap digestibility was not affected ( $p>0.05)$ by the amount of supplemental starch. Ruminal ammonia nitrogen concentrations were higher $(\mathrm{p}<0.05)$ in supplemented animals, however, a negative linear effect $(\mathrm{p}<0.05)$ of amount of starch was observed. Supplements increased $(p<0.05)$ the nitrogen balance $(\mathrm{NB})$ and efficiency of nitrogen utilization. These effects were attributed to increased body anabolism, supported by higher $(\mathrm{p}<0.05)$ serum concentration of insulin-like growth factor 1 . Increasing the amount of starch tended $(\mathrm{p}<0.06)$ to linearly increase the NB. In spite of this, there was a highest NB value for the 2:1 starch:CP ratio amongst the treatments with supplementation. Conclusion: Nitrogen supplementation in cattle fed low-quality tropical forage increases nitrogen retention in the animal's body. An additional supply of starch increases nitrogen retention by increasing energy availability for both rumen and animal metabolism.

Keywords: Brachiaria decumbens; Digestibility; Fibre; Nitrogen Balance; Zebu

\section{INTRODUCTION}

The low-quality of tropical forages during the dry season of the year is a result of reduced crude protein $(\mathrm{CP})$ contents and higher lignification of insoluble fibre. The $\mathrm{CP}$ contents are usually below the critical values for the rumen microorganisms present full capacity for fibre degradation ( $<70$ to $80 \mathrm{~g} \mathrm{CP} / \mathrm{kg}$ of dry matter [DM]) [1,2].

In tropical conditions, supplementation with nitrogenous compounds is the most important in 
improving the use of low-quality forages [3,4]. On the other hand, negative effects can be observed on low-quality forage intake and utilisation in animals supplemented with non-fibrous carbohydrates $[4,5]$. Under these conditions, a decreased fibre utilisation could occur because of an increase in the competition for essential nutrients between fibrolytic and non-fibrolytic microbial species [6].

Despite the fact, studies conducted in the tropics have reported that the association between energy and nitrogen supplements may involve interactive effects on the metabolism of nitrogenous compounds that could override the deleterious effects on ruminal degradation of fibre when only energy supplementation is used. This may increase the production of rumen microbial nitrogen and dietary energy, possibly by avoiding the effects of competition between fibrolytic and non-fibrolytic species [3,7]. In these conditions, effects that maximize nitrogen retention in the animal's body can also be observed, which implies increased weight gain [7].

However, research illustrating the relationship between energy and nitrogen in supplements for animals fed low-quality tropical forages, and its effects on the metabolic and nutritional efficiencies are still scarce in the tropics.

Thus, the objective of this study was to evaluate the effects of supplementation with nitrogenous compounds associated with different levels of starch on voluntary intake, digestibility, and rumen and metabolic characteristics of cattle fed low-quality tropical forage.

\section{MATERIAL AND METHODS}

The experiment was carried out at the Department of Animal Science of the Universidade Federal de Viçosa, Viçosa, Minas Gerais state, Brazil.

Five 10 months old crossbred bulls (1/2 European $\times 1 / 2$ Zebu; averaging $186 \pm 7 \mathrm{~kg}$ of initial body weight [BW] $-209 \pm 12 \mathrm{~kg}$ of final BW, and $198 \pm 10 \mathrm{~kg}$ of average BW) were used. The animals were surgically fitted with ruminal and abomasal cannulas approximately 30 days prior the experiment. All surgical and animal care procedures were approved by the Animal Ethics Committee of the Universidade Federal de Viçosa, that was registered under the protocol number 112/2014.

The experiment was performed according to a $5 \times 5$ Latin square design, with five experimental periods lasting 15 days each. The first seven days of each period were used for adaptation of the animal to experimental diets. The animals were fed ad libitum with low-quality tropical forage (Brachiaria decumbens hay) with an average CP level of 7.4\%, on DM basis (Table 1). The animals were kept in individual pens, with approximately $10 \mathrm{~m}^{2}$, with unrestricted access to water and mineral mixture. Prior to the beginning of the experiment, the animals were adapted during 15 days to handling, facilities and forage allowance.

The animals were fed forage ad libitum at $0600 \mathrm{~h}$ and $1800 \mathrm{~h}$,
Table 1. Chemical composition of tropical hay, and two supplements (protein supplement and starch)

\begin{tabular}{lccc}
\hline Nutrient & Hay & Protein supplement & Starch \\
\hline DM (\% as fed) & 92.6 & 91.8 & 88.8 \\
OM (\% DM) & 95.3 & 98.6 & 99.8 \\
CP (\% DM) & 7.4 & 114.0 & 0.5 \\
EE (\% DM) & 0.5 & 0.3 & 0.3 \\
NDFap (\% DM) & 80.9 & - & - \\
NDIP (\% DM) & 4.3 & - & - \\
Lignin (\% DM) & 7.3 & - & - \\
iNDF (\% DM) & 38.1 & - & - \\
\hline
\end{tabular}

DM, dry matter; OM, organic matter; CP, crude protein; EE, ether extract; NDFap, neutral detergent fibre corrected for ash and protein; NDIP, neutral detergent insoluble protein; iNDF, indigestible neutral detergent fibre.

allowing approximately $10 \%$ in orts. The total amount of supplement was divided into two parts of equal weight packed in paper bags, which were placed in the rumen of animals at the same time of forage allowance.

The following treatments were evaluated: control (only forage), supplementation with $300 \mathrm{~g} \mathrm{CP} / \mathrm{d}$ (0:1), supplementation with $300 \mathrm{~g}$ starch/d and $300 \mathrm{~g} \mathrm{CP} / \mathrm{d}$ (1:1), supplementation with $600 \mathrm{~g}$ starch/d and $300 \mathrm{~g} \mathrm{CP} / \mathrm{d}(2: 1)$, and supplementation with $900 \mathrm{~g}$ starch/d and $300 \mathrm{~g} \mathrm{CP} / \mathrm{d}(3: 1)$.

The amount of nitrogen supplement $(300 \mathrm{~g} \mathrm{CP} / \mathrm{d})$ corresponded to approximately $55 \%$ of the dietary requirements of $\mathrm{CP}$ for crossbred young bulls (European $\times Z e b u$ ) with BW of $200 \mathrm{~kg}$ and expected gain of $0.5 \mathrm{~kg} / \mathrm{d}$ [8]. A mixture of nitrogenous compounds provided $1 / 3$ from true protein (casein) and $2 / 3$ from non-protein nitrogen (mixture of urea and ammonium sulphate, 9:1) was used as the nitrogen supplement [9]. In order to supply energy, a unique source of corn starch was used. The energy supplementation was added to a ratio of $0,1,2$, and 3 times the equivalent weight of $\mathrm{CP}$.

The voluntary intake and total digestibility were evaluated from the 8th to 14th day. In this sense, the amounts of supplied hay (8th to 13th $\mathrm{d}$ ) and orts (9th to 14th $\mathrm{d}$ ) were taken into account. Forage and orts samples were pooled per animal and experimental period.

Total collection of faeces was held on 10th, 12th, and 14th days of each experimental period, starting at $0600 \mathrm{~h}$. At the end of each collection day, the faeces were weighed, homogenized and an aliquot of approximately $50 \mathrm{~g} / \mathrm{kg}$ was taken and oven-dried $\left(60^{\circ} \mathrm{C}\right)$.

Total collection of urine was performed on the 17th $\mathrm{d}$ of each period using funnel collectors coupled in the penile region and secured by elastic straps on the back of the animals. The funnels were equipped with hoses, which led the urine to polyethylene containers. The containers were maintained inside a Styrofoam box with ice that was replaced constantly. Urine collections began at 0600 hours and lasted $24 \mathrm{~h}$, which is enough to represents an entire period and to evaluate urinary excretion [10]. After 24 hours, the total volume of urine was measured, and two aliquots 
per animal and experimental period were obtained. The first one was used for evaluation of total nitrogen (Kjeldahl procedure) and urea (enzymatic colorimetric method with clearance factor of lipids; Human 10505, Wiesbaden, Hessen, Germany) contents. The second aliquot was frozen $\left(-80^{\circ} \mathrm{C}\right)$ and sent to a commercial laboratory for the quantification of 3-methylhistidine by using high-performance liquid chromatography (HPLC). The data for 3-methylhistidine was presented in relation to urinary creatinine excretion.

Rumen fluid samples were taken on the 16th day at $0600 \mathrm{~h}$, $1200 \mathrm{~h}, 1800 \mathrm{~h}$, and $2400 \mathrm{~h}$ to evaluate $\mathrm{pH}$ and ruminal ammonia nitrogen (RAN) concentrations. The samples were collected manually from the liquid/solid interface of the rumen mat, filtered through a triple cheesecloth layer and submitted to $\mathrm{pH}$ assessment through digital potentiometer. A $40 \mathrm{~mL}$ aliquot was then separated, fixed with $1 \mathrm{~mL}$ of a $\mathrm{H}_{2} \mathrm{SO}_{4}$ solution $(500 \mathrm{~mL} / \mathrm{L})$ and frozen $\left(-20^{\circ} \mathrm{C}\right)$ for further analysis of RAN .

Concurrently with the ruminal fluid, blood samples were taken from the animals directly from the jugular vein using tubes with vacuum and gel coagulation accelerator (BD Vacutainer, SST II Advance, São Paulo, SP, Brazil). The samples were immediately centrifuged $(2,700 \times \mathrm{g} ; 20$ minutes) to separate the serum. At the end of the day, samples were pooled per animal (equal volumes for each collection) that were sent to a commercial laboratory to be analysed for the concentration of free amino acids (HPLC; chromatography quantitative of amino acid), glucose (enzyme method glucose oxidase-peroxidase), insulin-like growth factor 1 (IGF1) (immunoradiometric assay; DSL-5600 IRMA Active), triglycerides (enzymatic-colorimetric method), and urea (as described for urine samples).

Hay, orts and faeces samples were processed in a Willey mill (1- and 2-mm). Subsequently hay, orts and faeces samples were compiled per animal and experimental period.

The samples processed to pass through the 1-mm screen sieve were evaluated for DM (method INCT-CA G-003/1), organic matter (OM; method INCT-CA M-001/1), CP (method INCTCA N-001/1), ether extract (EE; method INCT-CA G-005/1), neutral detergent fibre corrected for ash and protein (NDFap; methods INCT-CA F-002/1, INCT-CA M-002/1 and INCT-CA $\mathrm{N}-004 / 1$ ), neutral detergent insoluble protein (NDIP; method INCT-CA N-004/1) and lignin $\left(\mathrm{H}_{2} \mathrm{SO}_{4} 720 \mathrm{~g} / \mathrm{kg}\right.$; INCT-CA F005/1 method) according to the standard techniques of Brazilian National Institute of Science and Technology in Animal Science (INCT-CA; [11]).

Hay and orts samples processed to pass through the 2-mm screen sieve were evaluated for the indigestible NDF (iNDF; method INCT- CA 009/1) contents by using a 288-hours in situ incubation procedure.

The RAN contents were quantified by colorimetric technique adopted by the INCT-CA (method INCT-CA N-006/1). The concentrations obtained at different times were combined by animal and time to produce a single value that represented the average daily RAN concentration. Similar combination was conducted on rumen $\mathrm{pH}$ values.

The experiment was analysed according to a $5 \times 5$ Latin square design including the effects of treatment (fixed), animal (random), and experimental period (random). Comparisons between treatments were conducted through the decomposition of the sum of squares in orthogonal contrasts, which were responsible for the comparison between control treatment and treatments involving the supplementation and evaluation of the linear, quadratic and cubic effects of the ratios of starch to $\mathrm{CP}$ in the supplements. All statistical procedures were performed using the MIXED procedure of SAS $9.4(\alpha=0.05)$.

\section{RESULTS}

Supplements increased $(\mathrm{p}<0.05)$ the DM, OM (in $\mathrm{kg} / \mathrm{d}$ and $\mathrm{g} / \mathrm{kg}$ BW), CP, and digested OM (DOM) intakes, and the CP:DOM ratio in the diet. Supplements did not affect $(\mathrm{p}>0.05)$ the intake of forage, NDFap (kg/d and g/ $\mathrm{kg}$ BW) and digested NDFap (kg/d) (Table 2).

The inclusion of starch in the supplement linearly increased $(\mathrm{p}<0.05)$ the $\mathrm{DM}$ and OM intakes, when expressed in $\mathrm{kg} / \mathrm{d}$, and linearly decreased $(\mathrm{p}<0.05)$ the CP:DOM ratio in the diet. There were no effects $(p>0.05)$ of the proportion of starch in the supplement on forage, $\mathrm{CP}$ and NDFap intake, when expressed in $\mathrm{kg} / \mathrm{d}$ (Table 2).

On the other hand, a cubic effect $(\mathrm{p}<0.05)$ of the amount of starch in the supplement was found on DOM and digested NDFap intakes $(\mathrm{kg} / \mathrm{d})$ and on intakes of DM, forage, OM and NDFap when expressed in $\mathrm{g} / \mathrm{kg} \mathrm{BW}$. This pattern was attributed to higher intakes observed when adopted the starch:CP ratio of 2:1 (Table 2).

The provision of supplements increased $(\mathrm{p}<0.05)$ the dietary $\mathrm{DOM}$ and total $\mathrm{OM}$ and $\mathrm{CP}$ digestibilities. There was no effect ( $p>0.05$ ) when providing supplements on total NDFap digestibility (Table 3).

There was a linear positive effect $(\mathrm{p}<0.05)$ of the amount of starch in the supplement on the dietary DOM and total OM digestibility. There was a trend for a linear negative effect $(\mathrm{p}<0.07)$ on total CP digestibility according to the amount of starch in the supplement. The NDFap digestibility was not affected ( $p>0.05)$ by the amount of starch in the supplement (Table 3).

The RAN concentration was, on average, higher $(\mathrm{p}<0.05)$ in supplemented animals. There was no effect $(\mathrm{p}>0.05)$ of the supplementation on rumen $\mathrm{pH}$ (Table 4). Moreover, there was a negative linear effect $(\mathrm{p}<0.05)$ of the starch amount in the supplement on RAN concentration and ruminal $\mathrm{pH}$.

The nitrogen intake showed a similar pattern to the $\mathrm{CP}$ intake (Table 4). There was an overall increasing effect $(p<0.05)$ of the supplementation on the urinary nitrogen excretion (UNE), nitrogen balance (NB), efficiency of nitrogen utilization (ENU), urinary excretion of urea nitrogen (UEUN) and serum urea nitrogen 
Table 2. Average nutrient intake of bulls fed low feed value tropical hay with nitrogen and energy supplements

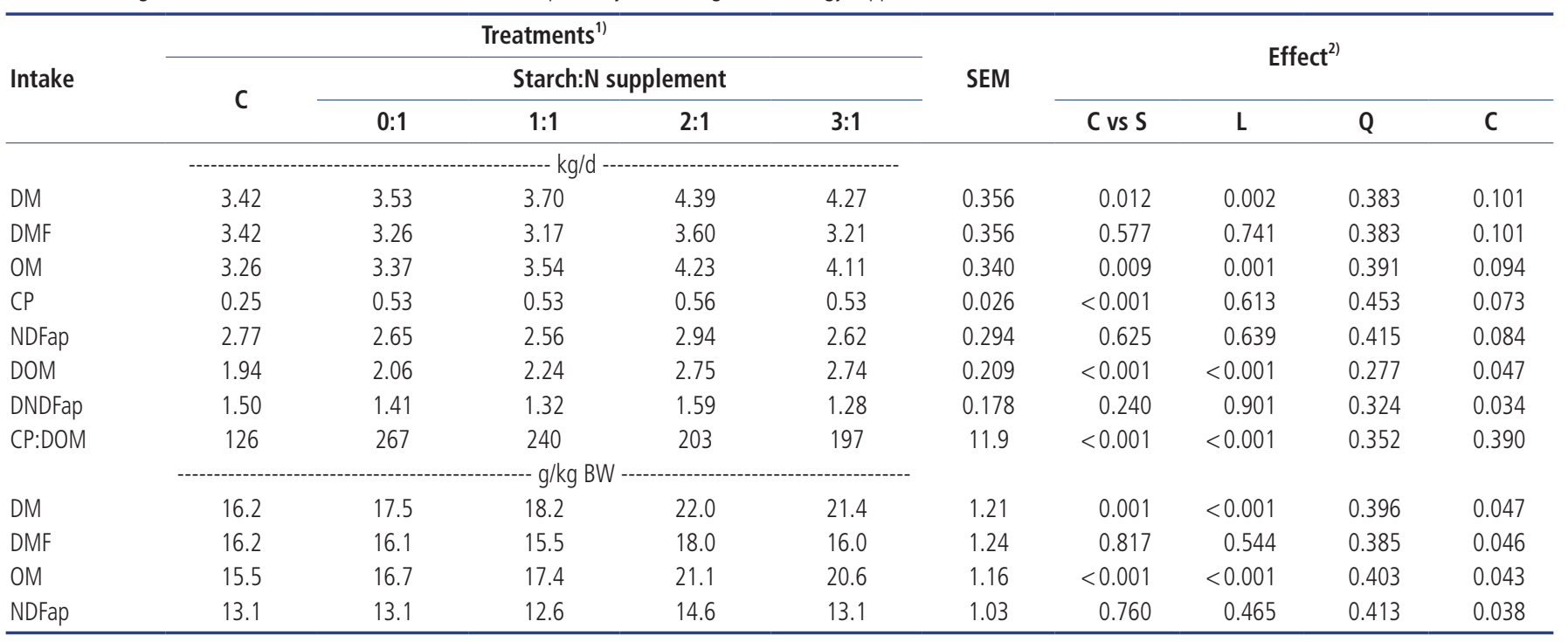

SEM, standard error of the mean; DM, dry matter; DMF, DM from forage; OM, organic matter; CP, crude protein; NDFap, neutral detergent fibre corrected for ash and protein; DOM, digested OM; DNDFap, digested NDFap; BW, body weight.

1) Control, no supplementation; $0: 1,1: 1,2: 1,3: 1$, starch:crude protein ratio in the supplement $(\mathrm{g} / \mathrm{g})$.

${ }^{2)}$ C vs $S$, control versus supplementation; $L, Q, C$, linear, quadratic, and cubic effects of starch:crude protein ratio in the supplement.

concentration (SUN). There was no effect ( $\mathrm{p}>0.05)$ of supplementation on faecal nitrogen excretion (FNE), blood amino acids concentration and ratio of urinary 3-methylhistidine:creatinine (Table 4).

There was a negative linear effect $(\mathrm{p}<0.05)$ of the starch amount in the supplement on UNE, UEUN, and SUN. Moreover, there was a trend of linear increase of $\mathrm{NB}(\mathrm{p}<0.06)$ and ENU $(\mathrm{p}<0.07)$ with the increase in the amount of starch in the supplement. The variation in the amount of starch did not affect ( $p>0.05$ ) FNE, blood amino acids concentration and ratio of urinary 3-methylhistidine: creatinine (Table 4).

Only the serum IGF1 concentration was affected $(\mathrm{p}<0.05)$ by the supplement supply, with higher values being verified in supplemented animals. Blood glucose and triglycerides were not affected $(\mathrm{p}>0.05)$ on average, by supplementation (Table 4$)$.

There was a linear increase $(\mathrm{p}<0.05)$ in the amount of starch in the supplement on blood concentration of IGF1. The serum glucose and triglyceride concentrations were unaffected $(\mathrm{p}>0.05)$ by different amounts of starch in the supplement (Table 4).

\section{DISCUSSION}

In general, supplementation of animals consuming low-quality forage with nitrogenous compounds has the potential to provide substrates to the rumen environment, which would favour the growth of fibrolytic bacteria. As a consequence, fibre degradation and forage intake increased $[4,12,13]$. However, a positive effect of the nitrogen supplements on forage intake (Table 2) and fibre digestibility (Table 3) was not verified. According to Lazzarini et al [1] and Van Soest [14], responses to nitrogen supplementation on forage intake become less apparent when the $\mathrm{CP}$ content of the basal forage is greater than $7 \%$ to $8 \% \mathrm{DM}$, such as the forage used in this study (Table 1).

However, by considering that supplementation increased DM and OM intakes (Table 2), but did not affect forage intake (Table 2 ), it can be understood that supplementation with starch and nitrogenous compounds, in general, did not cause any substitutive effect on forage intake. The substitutive effect caused by supplements is positively correlated with forage quality [15]. Thus,

Table 3. Means of digestibilities of OM, CP, and NDFap (\%) and dietary digested organic matter (DOM, g/kg) and treatment effects

\begin{tabular}{|c|c|c|c|c|c|c|c|c|c|c|}
\hline \multirow{3}{*}{ Item } & \multicolumn{5}{|c|}{ Treatments $^{1)}$} & \multirow{3}{*}{ SEM } & \multirow{2}{*}{\multicolumn{4}{|c|}{ Effect $^{2)}$}} \\
\hline & \multirow{2}{*}{ C } & \multicolumn{4}{|c|}{ Starch:N supplement } & & & & & \\
\hline & & $0: 1$ & $1: 1$ & $2: 1$ & $3: 1$ & & C vs S & $\mathbf{L}$ & Q & C \\
\hline OM & 59.6 & 61.1 & 63.9 & 65.2 & 66.4 & 1.70 & 0.032 & 0.040 & 0.643 & 0.872 \\
\hline $\mathrm{CP}$ & 46.5 & 75.2 & 74.4 & 71.5 & 71.0 & 1.68 & $<0.001$ & 0.062 & 0.922 & 0.543 \\
\hline NDFap & 58.8 & 57.6 & 57.2 & 57.5 & 55.1 & 2.27 & 0.407 & 0.444 & 0.617 & 0.703 \\
\hline DOM & 569 & 584 & 611 & 627 & 640 & 16.2 & 0.024 & 0.025 & 0.668 & 0.933 \\
\hline
\end{tabular}

SEM, standard error of the mean; DM, dry matter; OM, organic matter; CP, crude protein; NDFap, neutral detergent fibre corrected for ash and protein; DOM, digested OM.

1) Control, no supplementation; $0: 1,1: 1,2: 1,3: 1$, starch:crude protein ratio in the supplement $(\mathrm{g} / \mathrm{g})$.

${ }^{2)} \mathrm{C}$ vs S: control versus supplementation; $L, Q, C$, linear, quadratic, and cubic effects of starch:crude protein ratio in the supplement. 
Table 4. Means of the metabolic characteristics of bulls fed low feed value tropical hay with nitrogen and energy supplements

\begin{tabular}{|c|c|c|c|c|c|c|c|c|c|c|}
\hline \multirow{3}{*}{ Item } & \multicolumn{5}{|c|}{ Treatments $^{1)}$} & \multirow{3}{*}{ SEM } & \multirow{2}{*}{\multicolumn{4}{|c|}{ Effect $^{2)}$}} \\
\hline & \multirow{2}{*}{ C } & \multicolumn{4}{|c|}{ Starch:N supplement } & & & & & \\
\hline & & $0: 1$ & $1: 1$ & $2: 1$ & $3: 1$ & & C vs S & $\mathrm{L}$ & Q & $\mathrm{C}$ \\
\hline RAN (mg/dL) & 3.59 & 29.95 & 20.77 & 18.28 & 10.26 & 3.521 & $<0.001$ & $<0.001$ & 0.852 & 0.387 \\
\hline $\mathrm{pH}$ & 6.52 & 6.55 & 6.37 & 6.41 & 6.23 & 0.114 & 0.146 & 0.016 & 0.979 & 0.229 \\
\hline $\mathrm{NI}(\mathrm{g} / \mathrm{d})$ & 39.4 & 85.3 & 83.8 & 89.4 & 84.9 & 4.12 & $<0.001$ & 0.612 & 0.456 & 0.072 \\
\hline UNE (g/d) & 16.0 & 40.8 & 41.4 & 29.6 & 29.0 & 4.57 & $<0.001$ & 0.018 & 0.874 & 0.200 \\
\hline FNE (g/d) & 21.2 & 21.3 & 21.7 & 25.7 & 24.6 & 2.35 & 0.362 & 0.144 & 0.716 & 0.349 \\
\hline$N B(g / d)$ & 2.3 & 23.2 & 20.7 & 34.1 & 31.4 & 4.44 & $<0.001$ & 0.058 & 0.980 & 0.104 \\
\hline ENU (g of retained N/g of ingested N) & 0.041 & 0.272 & 0.246 & 0.377 & 0.372 & 0.0517 & $<0.001$ & 0.069 & 0.828 & 0.198 \\
\hline UEUN (g/d) & 10.0 & 38.3 & 37.1 & 29.4 & 24.5 & 4.60 & $<0.001$ & 0.006 & 0.583 & 0.551 \\
\hline SUN (mg/dL) & 9.2 & 27.8 & 23.5 & 19.8 & 16.3 & 2.12 & $<0.001$ & $<0.001$ & 0.793 & 0.938 \\
\hline 3MH:cre (mmol/g creatinine) & 98.0 & 77.3 & 80.9 & 91.6 & 97.4 & 19.21 & 0.316 & 0.151 & 0.912 & 0.787 \\
\hline $\mathrm{AA}(\mathrm{mol} / \mathrm{L})$ & 2238 & 2181 & 2172 & 2365 & 2268 & 226.3 & 0.936 & 0.497 & 0.872 & 0.564 \\
\hline Glucose (mg/dL) & 54.4 & 57.4 & 59.3 & 56.9 & 57.8 & 5.20 & 0.083 & 0.872 & 0.765 & 0.319 \\
\hline Triglycerides (mg/dL) & 19.7 & 21.4 & 24.0 & 21.2 & 21.6 & 3.07 & 0.193 & 0.752 & 0.484 & 0.231 \\
\hline IGF1 (ng/mL) & 38.6 & 40.4 & 76.0 & 80.0 & 95.5 & 15.35 & 0.014 & 0.005 & 0.297 & 0.413 \\
\hline
\end{tabular}

SEM, standard error of the mean; RAN, ruminal ammonia nitrogen concentration; NI, nitrogen intake; UNE, urinary nitrogen excretion; FNE, faecal nitrogen excretion; NB, nitrogen balance; ENU, efficiency of nitrogen utilization; UEUN, urinary excretion of urea nitrogen; SUN, serum urea nitrogen concentration; 3MH:cre, ratio of urinary 3-methylhistidine:creatinine; $A \mathrm{~A}$, blood concentrations of amino acids; IGF1, insulin-like growth factor 1.

1) Control, no supplementation; 0:1, 1:1, 2:1, 3:1, starch:crude protein ratio in the supplement (g/g).

${ }^{2)} \mathrm{C}$ vs $\mathrm{S}$, control versus supplementation; $L, Q, C$, linear, quadratic, and cubic effects of starch:crude protein ratio in the supplement.

even with the additional starch supply, the low-quality forage used in this experiment seems to be the main reason of the absence of substitutive effect.

The increased DOM intake observed with the supplement supply (Table 2) reflects only the addition of high digestibility components to the diet, since there were no effects of supplementation on digested NDFap intake (Table 2) and NDFap digestibility (Table 3).

The evaluation of intake pattern among supplements, especially with values expressed in relation to $\mathrm{BW}$, indicate that the amount of starch produced a cubic effect on total and forage intake, which is justified by the most prominent intake observed when the starch:CP ratio used in supplement was 2:1 (Table 2). This behaviour contrasts with the linear increase of the starch amount on the diet energy content, supported by the linear effects on the dietary DOM (Table 3) and CP:DOM (Table 2).

The control of feed intake by ruminants is a complex multifactorial process in which animals aim at reaching the minimal total discomfort [16]. In this sense, even when provided lowquality forages, mechanisms related to physical gastrointestinal distension and metabolic regulation act simultaneously on the control of feed intake [17]. Among the metabolic mechanisms, the dietary energy-to-protein ratio plays a preponderant role, since excess of available energy in relation to protein availability may cause discomfort because of the increased body heat production. By contrast, excess of protein availability in relation to available energy can extend the discomfort by excessive nitrogenous compounds catabolism $[18,19]$. Thus, it may be understood that under the feed conditions of this study, the use of a starch:CP ratio of 2:1 promoted, amongst the evaluated supplements, a closer condition of comfort (Table 2). It is noteworthy that, even without an overall effect of supplementation on intake, forage intake using the starch: $\mathrm{CP}$ ratio of $2: 1$ was approximately $11 \%$ higher (in $\mathrm{g} / \mathrm{kg} \mathrm{BW}$ ) compared to the control.

Studies conducted in the tropical environment have reported decreases in NDFap digestibility with supplement starch [4,7]. It was reasoned with increasing dominance of non-fibrolytic bacteria species than fibrolytic bacteria in the rumen, which depresses the fibrolytic activity $[20,21,22]$. However, the increase starch supplement did not affect fibre digestion in this study (Table 3). Moreover, it must be noted that the starch supply was done together with nitrogenous compounds. In these situations, the increased availability of nitrogen can decrease the microbial competition for substrates, reducing or avoiding the deleterious effects on fibre degradation, as shown by other authors $[4,7]$.

The most prominent effects of supplement supply consisted of increasing NB and ENU (Table 4). This effect must be attributed to an increase in nitrogen status in the animal organism [23,24]. The term "protein status" or "nitrogen status" defines the quantitative and qualitative availability of nitrogen supplements for all physiological functions in animal metabolism, including the functions associated with the metabolism of other compounds (e.g., energy) [25]. The nitrogen supplements available for the animal metabolism would be used for different metabolic functions in a priority order for the animal as follows: survival (e.g., nitrogen recycle), maintenance and production (e.g., growth, reproduction, etc.). Therefore, nitrogen deposition in body tissues or products will only occur after supplying the demands of nitrogen supplementation of higher priority [25]. Thus, the increase in NB and ENU reflects in an improved nitrogen availability for animal 
growth and in a decrease in nitrogen proportion used for either maintenance or surviving functions caused by nitrogen supplementation (Table 4).

Some authors have found that the nitrogen supply can decrease the muscle protein catabolism for use in metabolic demands of higher priority $[26,27]$. However, the supplement supply did not affect the ratio of urinary 3-methylhistidine:creatinine (Table 4), which is a direct indicator of muscle protein catabolism.

However, the supplements enhanced the serum concentration of IGF1 (Table 4), indicating that the effects of increased nitrogen supply were essentially anabolic. The IGF1 is an endocrine regulator of muscle growth in cattle. In addition to their independent action, it promotes important links between growth hormone and the metabolic growth process $[28,29]$, particularly in skeletal muscle [30]. The IGF1 concentrations are responsive to nutritional plane as well as the diet composition, with an apparently more prominent response to dietary protein concentration than energy concentration [29]. This justifies the increase of its serum concentration with the nitrogen supply. Similar results were obtained by Rufino [31], who supplemented cattle fed tropical forage and supplemented with nitrogenous compounds.

In addition, it was found that the supplementation tended $(\mathrm{p}<0.09)$ to increase the blood glucose concentration (Table 4). This seems to support the idea of enhancing the nitrogen status in the animal organism with nitrogen supplementation. Part of glucose demanded by the ruminant can be synthesized from gluconeogenic amino acids [14]. However, low nitrogen availability could increase the demand of amino acids for hepatic urea synthesis [32]. Thus, the additional nitrogen supply could incur less use of gluconeogenic amino acids in the intermediary metabolism of nitrogen, enhancing as a consequence the availability of precursors for the glucose synthesis [31].

The increased levels of starch in the supplement lowered ruminal $\mathrm{pH}$ values, and this did not negatively affect the normal ruminal fermentation pattern. Comparing the results obtained between supplements, it was found that the increase in the starch amount tended to increase the NB $(\mathrm{p}<0.06)$. Part of this effect appears to result from higher efficiency of microbial nitrogen utilization in the rumen. This argument is based on the linear decrease of RAN and SUN concentrations as starch supply increased. Additionally, the CP digestibility was decreased with the increase in starch supply (Table 3), which may reflect lesser loss of nitrogen as ammonia in the rumen. Whereas the nitrogen intake was similar for all supplements (Table 4), the decrease of those variables (i.e., RAN and SUN) could only be obtained through a better efficiency of microbial nitrogen utilization in the rumen. The increase in nitrogen assimilation by providing additional starch was reported under tropical grass feeding $[4,7]$. Greater microbial nitrogen assimilation implies an increase in metabolisable protein (MP) supply. This is supported by no significant changes in faecal nitrogen excretion (Table 4), indicating that any additional microbial nitrogen produced with the starch supplementation was actually digested in the intestine and, therefore, converted to MP.

However, according to Detmann et al [27], increases in MP supply from microbial origin account for only $18.5 \%$ of the observed increase in NB in cattle fed tropical forages. This indicates that secondary or metabolic effects of supplementation also affect the efficiency of nitrogen utilization in the animal organism.

In ruminants, the protein deposition efficiency depends on the energy availability, additionally, the efficiency of energy utilization in the metabolism depends on the amino acids availability [33]. Thus, the starch supplement seems to have increased the availability of metabolisable energy, which resulted in an increase in nitrogen retention in the animal organism. This hypothesis is reinforced by the linear decrease in the nitrogen losses in the urine by increasing the starch amount in the supplement (Table 4). It is noteworthy that there has been a linear increase in the blood concentration of IGF1 with the increase in the starch supply (Table 4), confirming the increase in body anabolism with the increased starch supply.

In relation to increasing trend in the $\mathrm{NB}$ with the increasing starch supplement level, means indicated highest value for starch: $\mathrm{CP}$ ratio of 2:1 (Table 4). This pattern is associated with the arguments made on voluntary intake, indicating that higher metabolic comfort adaptation may have been obtained with this ratio.

\section{IMPLICATIONS}

Nitrogen supplementation in cattle fed low-quality tropical forage increases nitrogen retention in the animal mainly by raising the nitrogen status in the body. However, an additional starch supply is able to enhance nitrogen retention through increasing the energy availability in the rumen and animal metabolism. Among the starch:CP ratios, 2 to 1 is most recommendable.

\section{CONFLICT OF INTEREST}

We certify that there is no conflict of interest with any financial organization regarding the material discussed in the manuscript.

\section{ACKNOWLEDGMENTS}

The authors wish to thank the INCT-Ciência Animal, Conselho Nacional de Pesquisa e Desenvolvimento Científico e Tecnológico $(\mathrm{CNPq})$ and Fundação de Amparo à Pesquisa de Minas Gerais (FAPEMIG) for financial support.

\section{REFERENCES}

1. Lazzarini I, Detmann E, Sampaio CB, et al. Intake and digestibility in cattle fed low-quality tropical forage and supplemented with nitrogenous compounds. R Bras Zootec 2009;38:2021-30.

2. Figueiras JF, Detmann E, Paulino MF, et al. Intake and digestibility 
in cattle under grazing supplemented with nitrogenous compounds during dry season. R Bras Zootec 2010;39:1303-12.

3. Detmann E, Paulino MF, Valadares Filho SC. Otimização do uso de recursos forrageiros basais. In: Simpósio de Produção de Gado de Corte. Viçosa: DZO-UFV; 2010. p. 191-240.

4. Souza MA, Detmann E, Paulino MF, et al. Intake, digestibility and rumen dynamics of neutral detergent fibre in cattle fed low-quality tropical forage and supplemented with nitrogen and/or starch. Trop Anim Health Prod 2010;42:1299-310.

5. Mlay PS, Pereka AE, Balthazary S, et al. In situ degradation of poor quality hay in the rumens of mature heifers as influenced by sugar, starch and nitrogen supplements and an ionic feed additive. Tanzania Vet J 2007;24:23-37.

6. Costa VAC, Detmann E, Valadares Filho SC, et al. In vitro degradation of low-quality tropical forage neutral detergent fiber according to protein and (or) carbohydrates supplementation. R Bras Zootec 2008;37:494-503.

7. Lazzarini I, Detmann E, Valadares Filho SC, et al. Nutritional performance of cattle grazing during rainy season with nitrogen and starch supplementation. Asian-Australas J Anim Sci 2016;29:1120-8.

8. Marcondes MI, Gionbelli MP, Valadares Filho SC, Chizzotti ML, Paulino MF. Protein requirements of zebu beef cattle. In: Valadares Filho SC, Marcondes MI, Chizzotti ML, Paulino PVR, editors. Nutrient requirements of zebu beef cattle BR-CORTE. Viçosa, Brazil: DZOUFV; 2010. p. 107-26.

9. Costa VAC, Detmann E, Paulino MF, et al. Total and partial digestibility and nitrogen balance in grazing cattle supplemented with non-protein and, or true protein nitrogen during the rainy season. R Bras Zootec 2011;40:2815-26.

10. Barbosa AM, Valadares RFD, Valadares Filho SC, et al. Effect of urinary collection days, concentrate levels and protein sources on creatinine, urea and purine derivatives excretions and microbial protein synthesis in Nellore cattle. R Bras Zootec 2006;35:870-7.

11. Detmann E, Souza MA, Valadares Filho SC, et al. Métodos para análise de alimentos. Visconde do Rio Branco: Suprema; 2012.

12. Detmann E, Paulino MF, Mantovani HC, et al. Parameterization of ruminal fibre degradation in low-quality tropical forage using MichaelisMenten kinetics. Livest Sci 2009;126:136-46.

13. Leng RA. Factors affecting the utilization of "poor-quality" forages by ruminants particularly under tropical conditions. Nutr Res Rev 1990;3:277-303.

14. Van Soest PJ. Nutritional ecology of the ruminant. 2nd ed. Ithaca, NY: Cornell University Press; 1994.

15. Minson DJ. Animal feeding and nutrition. San Diego, CA: Academic Press; 1990.

16. Forbes JM. A personal view of how ruminant animals control their intake and choice of food: minimal total discomfort. Nutr Res Rev 2007;20:132-46.

17. Detmann E, Gionbelli MP, Huhtanen P. A meta-analytical evaluation of the regulation of voluntary intake in cattle fed tropical forage-based diets. J Anim Sci 2014;92:4632-41.
18. Illius AW, Jessop NS. Metabolic constraints on voluntary intake in ruminants. J Anim Sci 1996;74:3052-62.

19. Poppi DP, McLennan SR. Protein and energy utilization by ruminants at pasture. J Anim Sci 1995;73:278-90.

20. Carvalho IPC, Detmann E, Mantovani HC, et al. Growth and antimicrobial activity of lactic acid bacteria from rumen fluid according to energy or nitrogen source. R Bras Zootec 2011;40:1260-5.

21. El-Shazly K, Dehority BA, Johnson RR. Effect of starch on the digestion of cellulose in vitro and in vivo by rumen microorganisms. J Anim Sci 1961;20:268-73.

22. Mould FL, Ørskov ER, Mann SO. Associative effects of mixed feeds. I. effects of type and level of supplementation and the influence of the rumen fluid $\mathrm{pH}$ on cellulolysis in vivo and dry matter digestion of various roughages. Anim Feed Sci Technol 1983;10:15-30.

23. Egan AR, Moir RJ. Nutritional status and intake regulation in sheep. 1. Effects of duodenally infused single doses of casein, urea and propionate upon voluntary intake of a low-protein roughage by sheep. Aust J Agric Res 1965;16:437-49.

24. Egan AR. Nutritional status and intake regulation in sheep. 2. The influence of sustained duodenal infusions of casein or urea upon voluntary intake of low-protein roughages by sheep. Aust J Agric Res 1965;16:451-61.

25. Detmann E, Valente EEL, Batista ED, Huhtanen P. An evaluation of the performance and efficiency of nitrogen utilization in cattle fed tropical grass pastures with supplementation. Livest Sci 2014;162: 141-53.

26. Rufino LMA, Detmann E, Gomes DI, et al. Intake, digestibility and nitrogen utilization in cattle fed tropical forage and supplemented with protein in the rumen, abomasum, or both. J Anim Sci Biotechnol 2016; 7:11.

27. Detmann E, Paulino MF, Valadares Filho SC, Huhtanen P. Nutritional aspects applied to grazing cattle in tropics: a review based on Brazilian results. Semina Ciênc Agric 2014;35(4Suppl):2829-54.

28. Drewnoski ME, Huntington GB, Poore MH. Reduced supplementation frequency increased insulin-like growth factor 1 in beef steers fed medium quality hay and supplemented with a soybean hull and corn gluten feed blend. J Anim Sci 2014;92:2546-53.

29. Pell JM, Bates PC. The nutritional regulation of growth hormone action. Nutr Res Rev 1990;3:163-92.

30. Lobley GE. Control of the metabolic fate of amino acids in ruminants: a review. J Anim Sci 1992;70:3264-75.

31. Rufino LMA. Nutritional performance and metabolic characteristics in cattle fed tropical forages in response to infrequent supplementation with nitrogenous compounds [Ph.D thesis]. Viçosa, MG: Universidade Federal de Viçosa; 2015.

32. Parker DS, Lomax MA, Seal CJ, Wilton JC. Metabolic implications of ammonia production in the ruminant. Proc Nutr Soc 1995;54: 549-63.

33. Schroeder GF, Titgemeyer EC. Interaction between protein and energy supply on protein utilization in growing cattle: A review. Livest Sci 2008;114:1-10 